\title{
Конкретика асимметричной войны: фрагменты опыта
}

\author{
Джузеппе Кафорио*
}

\section{Введение}

Термин асимметричная война употребляется тогда, когда более слабый противник сталкивается с более сильным, и когда используются способы боевых действий, которые существенно отличаются от традиционной военной тактики. Именно использование нетрадиционных методов позволяет более слабой стороне выстоять против более сильного врага. ${ }^{1}$ Коренное отличие асимметричного образа военных действий от того, который сегодня обозначается как конвенциональный, состоит как в этических аспектах конфликта и характере боевых действий, обычно имеющих место, так и в используемых инструментах и стратегиях.

Этический аспект, который характеризует асимметричную войну, выражается в пренебрежении всеми этическими нормами, регламентирующими ведение военных действий, воспринятыми большинством развитых государств, и их замещение этикой, основанной на религиозном и/или политическом фанатизме, пренебрежении к человеческой жизни и оправдании любых средств борьбы, обеспечивающих достижение конечной цели. Цели борьбы, похоже, никогда не обсуждаются, и психологическое состояние тех, кто принимает участие в таких боевых действиях, в целом характеризуется лозунгом «победа или смерть».

Конкретные акты асимметричной войны используются для воспитания молодого поколения в духе религиозного и/или националистического фанатизма, вплоть до принятия мученичества. Часто используются взрывные устройства, са-

Джузеппе Кафорио является генералом итальянской армии в отставке. Он был президентом Исследовательского комитета 01 «Вооруженные силы и разрешение конфликтов» Международной социологической ассоциации (в течение 12 лет), является вице-президентом Итальянского Университетского Центра Исторических и Военных Исследований, одним из учредителей и координатором рабочей группы ERGOMAS, а так же членом нескольких исследовательских институтов. Джузеппе Кафорио работает внешним консультантом правительственного Итальянского центра стратегических и военных исследований. Он является обладателем степени бакалавра в области стратегических исследований, права, политических наук и степени магистра в сфере коммуникационных наук.

1 В таких конфликтах сильные акторы обычно менее заинтересованы в победе в асимметричном конфликте, поскольку их выживание не находится под непосредственной угрозой. Этот пониженный уровень интереса часто приводит к повышенной политической уязвимости, т.е. раздраженная, уставшая от войны общественность или преследующая собственные интересы элита могут заставить лидеров остановить конфликт до того как будут достигнуты конечные цели войны. Прекращенные военные действия, в конечном итоге, часто приводят к политическим поражениям, особенно когда более слабому оппоненту нужно не выиграть войну, а просто уцелеть. Таким образом, асимметрия дает преимущество более слабой стороне. 
моубийственные взрывы, вооруженные нападения, целевые убийства, похищения (людей, даже не связанных с конфликтом, с целью получения выкупа), и запугивание населения. Использованные средства находятся в исключительно широком диапазоне: от традиционных вооружений до взрывчатых веществ и химического оружия, от всех средств психологической войны, пропаганды и индоктринации, информационных и коммуникационных технологий предоставляемых обществом в эпоху Интернета, до так называемой теневой экономики. Общая стратегия более слабого противника состоит в том, чтобы перенести войну на территорию более сильной стороны (которая обычно является индустриальным государством). Такие государства в результате многовековой эволюции отодвинули подобные конфликты вдаль от своих городов и сел за границы их мира.

\section{Практика асимметричной войны}

То, что этот тип конфликтов можно обоснованно включить в категорию «война», подтверждается статистическими данными: между январем 1990 и мартом 2012 года в результате террористических нападений во всем мире погибли 8254 человека и 12576 были ранены, причем число потерь за 1990-е в первом десятилетии двадцать первого века увеличилось на 560 процентов. ${ }^{2}$ Вся эта бойня имела место в периоде, который историки и политологи считают мирным для индустриальных стран (за исключением малых и удаленных войн в Афганистане и Ираке). Полезное в этом плане сравнение показывает, что во Второй иракской войне в Заливе общие потери коалиции составили 4836 убитыми, что является немногим больше половины потерь за двадцать лет асимметричного конфликта, включающего негосударственных акторов.

Надо подчеркнуть, что асимметричный конфликт включает не только столкновения между фундаменталистским исламом, представляемым Аль-Каидой, и индустриальными странами, как нередко думают из-за их сильного общественного влияния, - «Евреи, крестоносцы и их вероотступнические марионеточные режимы в исламском мире», согласно типичной исламистской фразеологии. Многие движения, и национальные, и международные, восприняли эту форму борьбы, как свидетельствует впечатляющий список, составленный Габриэлем Вейманном:

- На Ближнем Востоке: Хамас (Исламское движение сопротивления), ливанская Хезболла (Партия Бога), Бригады мучеников аль-Аксы, Фатах Танзим, Народный фронт освобождения Палестины (НФОП), Палестинский исламский джихад, движение Кахане, Народные моджахеды Ирана (НМИ - Муджахеддин-е-Халк), Рабочая партия Курдистана (ПКК) и базированные в Турции Партия народного демократического освободительного фронта $(\mathrm{DHKP} / \mathrm{C})$ и Исламский фронт всадников Великого Востока (IBDA-C);

2 Данные взяты из Википедии. 
- В Европе: движение басков ЭТА, Армата Корса (Корсиканская армия) и Ирландская республиканская армия (ИРА);

- В Латинской Америке: перуанские Тупак-Амару и Сияющий путь (Сендеро Луминосо), колумбийские Национально-освободительная армия (ЕЛН - Колумбия) и Революционные вооруженные силы (ФАРК);

- В Азии, Аль-Каида: японская Высшая истина (Аум Синрике), Ансар ал Ислам (Воины Ислама) в Ираке, японская Красная армия (JRA), Хизб-ул Муджахедин в Кашмире, Тигры освобождения Тамил-Илама (LTTE), Исламское движение Узбекистана (ИДУ), Исламский освободительный фронт Mopo (MILF) на Филиппинах, пакистанский Лашкаре-Тайба и повстанческое движение в Чечне. ${ }^{3}$

Хотя исламский фундаментализм, похоже, на настоящий момент является основным актором в сфере асимметричной войны, это не должно привести нас к ошибочному заключению, что это религия ислама в целом обеспечивает религиозную и идеологическую основу для такой формы борьбы. В исламском мире существует глубокое разделение между «умеренным» исламизмом, который проповедует мирное сосуществование между людьми и строго осуждает обращение к терроризму, и радикальным, фундаменталистским исламизмом, который защищает религиозное право шариат, стремится к созданию глобального халифата и оправдывает любое насильственное действие, совершенное под знаменем джи$x a \partial a$ для достижения этой цели. Примером отношения умеренного ислама к средствам и целям фундаменталистского мусульманства является недавно распространенное по Интернету заявление, опубликованное на исламском сайте, в котором «нижеподписавшиеся члены миролюбивого и умеренного большинства общества мусульман, возмущенные и отвращенные кощунственным кровопролитием, совершаемым во имя Аллаха, отвергаем как несовместимое с исламом поведение, все акты терроризма ... во всех его формах, взрывы, стрельбу, использование холодного оружия, похищения, угоны, массовые убийства, поскольку они несправедливо причиняют вред неповинным людям и наносят непоправимый вред исламу». Далее в заявлении отправлен призыв запретить любую протеррористическую риторику в мусульманских школах и медиа, «лишая заката все те организации, которые учат, инициируют, способствуют или организовывают и совершают акты терроризма», и отправлен призыв ко всему мусульманскому сообществу отвергнуть религиозные указы, которые террористические группы использовали для оправдания своих действий. ${ }^{4}$

3 Смотри: Gabriel Weimann, "How Modern Terrorism Uses the Internet," Journal of International Security Affairs 8 (Spring 2005): 1-5; доступно на: www.securityaffairs.org/issues/ 2005/08/weimann.php.

4 Полный текст заявления, наряду со списком конкретных действий, которые подписавшие отвергают, как неприсущие исламу, можно найти на: www.petitiononline.com/ No2Jihad/petition.html. 
В свете этой декларации и других заявлений более умеренных мусульман весьма поучительно звучит наблюдение Эндрю Пратта:

Сегодня ислам не является единственным источником религиозного террора ... Религиозный терроризм проистекает так же и из других религиозных сообществ. Достаточно пройтись по покрытому граффити католическому пригороду Богсайд Лондондерри, где оказалось исключительно трудно искоренить насилие между католиками и протестантами, чтобы оценить христианский вклад в религиозный терроризм. $^{5}$

Далее, чтобы точнее определить акторов, являющихся слабой стороной в асимметричной войне, полезно обратиться к общей дефиниции Мэри Калдор нового явления, характеризующего такие конфликты, которое она назвала «Новыми войнами»:

Типичным новым явлением являются вооруженные сети негосударственных и государственных акторов. В их число входят: паравоенные группы, организованные вокруг харизматического лидера, полевые командиры, контролирующие определенные районы, террористические ячейки, добровольцы-фанатики, такие как моджахеды, формирования регулярных войск или других структур безопасности, а так же наемники и частные военные компании. ${ }^{6}$

Целью настоящей статьи является исследование этих аспектов асимметричных войн в контексте конкретных эпизодов их реализации, рассматривая их как примеры уникального исторического опыта.

\section{Этические/идеологические аспекть}

Идеологии движений, которые прибегают к асимметричной войне, как правило, глобальны и всеохватны. Так происходит потому, что для слабых сторон в мире радикального ислама - которые сегодня чаще всех (хотя и не исключительно) используют такие техники - основной целью является создание всемирного халифата путем священной войны и повсеместного навязывания законов шариата. В 2006 году один из лидеров Аль-Каиды, Абу Мусаб аль-Заркауи, в интервью, данном незадолго до его смерти, объяснил основную цель джихадистов таким обра3ом:

Наша политическая программа ... это слова Пророка (мир его праху): «Я был послан с мечом в руках до того часа, пока люди не станут поклоняться одному Аллаху» ... вот это и определяет нашу политическую цель. Мы воюем во имя аллаха, пока не восторжествует закон аллаха, и первый шаг - это прогнать врага, затем создать исламское государство, далее мы продолжим завоевывать земли мусульман, чтобы вернуть их себе, и после этого мы будем воевать с куффарами (неверными), пока

5 Andrew Nichols Pratt, "Terrorism's Evolution: Yesterday, Today, and Forever," Connections: The Quaterly Journal 10:2 (Spring 2011): 1-33, цитата на с. 19.

6 Mary Kaldor, New and Old Wars: Organized Violence in a Globalized Era (London: Polity Press, 2001), 9. 
они не примут одного из трех. Я был послан с мечом в руках до того часа; вот наша политическая программа.?

Эта цель имеет свои локальные отголоски. К примеру, в мае 2010 года в заявлении, озаглавленном «Кто такие моджсахеды на Аравийском полуострове?», группа Аль-Каиды на Аравийском полуострове (АКАП) изложила свои цели как включающие «изгнание евреев и крестоносцев» с Аравийского полуострова. ${ }^{8}$ В Египте имели место похожие воззвания:

25 апреля медиа-центр Ибн Таймияха выпустил видео, показывающее шествие воинствующих исламистских сторонников, развевающих флаги, обычно ассоциируемых с традиционным джихадизмом, состоявшееся 19 апреля в городе Аль-шейх Зувейд на Синайском полуострове. На видео был показан человек, идентифицированный как Шейх Абу аль-Бара, проповедующий о важности ведения джихада, который сказал: «Джихад является обязанностью до тех пор, пока не будет освобожден и последний квадратный сантиметр мусульманской земли; следовательно, персональный джихад есть первейшая из наших обязанностей». ${ }^{9}$

Среди радикальных исламистов, принимающих участие в этих асимметричных конфликтах, запрещена любая терпимость в отношении других идеологий или религий (и проистекающая из этого возможность компромисса и договоренностей). Так например, мусульманский священнослужитель Абдул Насер Бенбрика (известный так же как Абу Бакр), в интервью от 2005 года заявил: «Я говорю вам, что моя религия [ислам] не признает других религий. Она их не признает. Единственный закон, который должен существовать здесь или где бы то ни было, это ислам». ${ }^{10}$

Отсутствие этических правил (даже в исламе) о поведении в асимметричной войне слабой стороны явным образом выражено лидером Аль-Каиды, движения, которое до сих пор наиболее успешно ведет такую войну: «В сегодняшних войнах нет никакой морали. Мы считаем, что злейшими ворами в мире и злейшими террористами являются американцы. Нам не нужно делать отличие между военными и гражданскими лицами. Что касается нас, все они для нас являются целями». ${ }^{11}$ Бен Ладен превозносил физическое уничтожение противника, не сомневаясь в

7 "Dialogue with Abu Musab Al-Zarqawi," interview with Al Qaeda media arm, 2006; доступно на: http://www.kavkazcenter.com/eng/content/2006/12/20/6921_print.html.

8 “Al Qaeda in the Arabian Peninsula," Jane's World Insurgency and Terrorism (5 April 2012); доступно на: http://articles.janes.com/articles/Janes-World-Insurgency-and-Terrorism/AlQaeda-in-the-Arabian-Peninsula-AQAP-International.html.

9 “OSINT Summary: Militant Islamists in Egypt's Sinai Call for Support of Syria Jihad," Jane's Terrorism and Security Monitor (1 Мау 2012); доступно на: http://articles.janes.com/articles/ Janes-Terrorism-And-Security-Monitor-2012/OSINT-Summary-Militant-Islamists-in-Egypt-sSinai-call-for-support-of-Syria-jihad.html.

10 Michelle Grattan, "I Must Preach Holy War, Says Teacher," The Age (Australia) (5 August 2005); доступно на www.theage.com.au/articles/2005/08/04/1123125857077.html?from=top5.

11 Интервью Усамы бен Ладена для "Nightline," ABC News (10 June 1998); доступно на: http://abcnews.go.com/2020/video/osama-bin-laden-interview-1998-13506629. 
своих словах. Что же касается самоубийственного взрыва на корабле ВМС США Коул в Йемене, Бен Ладен, произнося речь на бракосочетании своего сына в южном Кандагаре, сказал: «Части тел неверных разлетались как частички пыли. Если бы вы видели это своими глазами, то были бы очень довольны и ваши сердца исполнились бы радостью». ${ }^{12}$ В соответствии с версией ислама Бен Ладена, вести асимметричную войну под знаменем джихада практически является требованием веры, за которую верующих ожидает особенная награда: «Для каждого лучше убить одного американца, чем разбазаривать свои силы на что-нибудь другое». ${ }^{13}$ И, наконец: «В нашей религии для тех, кто принимает участие в джихаде, в другой жизни выделено специальное место». ${ }^{14}$

В этой системе этики жертвование своей жизнью во имя идеи является частью некоей «культуры смерти», что объясняет большое число последователей, совершающих самоубийственные взрывы, и на него могут рассчитывать движения, прибегающие к разным формам асимметричной войны. ${ }^{15}$ Как сказал Юнис аль-Астал, видный лидер Хамаса: «Наиболее возвышенной формой джихада является война во имя аллаха, что означает пожертвовать своей душой, воюя с врагом лицом к лицу, даже если это означает принять мученичество». ${ }^{16}$ Хасан Насрала, генеральный секретарь Хезболлы, озвучил похожие радикальные исламистские чувства в 2004 году по поводу ценности мученичества: «Мы нашли, как бить по евреям там, где они наиболее уязвимы. Евреи любят жизнь, поэтому жизнь будет то, что мы у них отберем. Мы победим потому, что они любят жизнь, а мы любим смерть». ${ }^{17}$ В соответствии с этим видением асимметричного конфликта каждый, принадлежащий к более сильной стороне, является легитимной целью для актов терроризма, независимо от пола, занятия и т.д. В телевизионной дискуссии 19 октября 2004 года на тему «Что такое террорист?» Мохаммед Елмастри, глава Ис-

12 Цитировано на свадьбе его сына в Кандагаре. "Osama bin Laden,” Wikiquote; доступно на: http://en.wikiquote.org/wiki/Osama_bin_Laden.

13 Интервью Усамы бен Ладена, "Frontline," PBS (May 1998); доступно на: www.pbs.org/ wgbh/pages/frontline/shows/binladen/who/interview.html. Scott Macleod, “Osama bin Laden: The Paladin of Jihad,” Time Magazine (6 May 1996); доступно на: www.time.com/time/magazine/article/0,9171,984493,00.html.

15 Как я писал в другом месте, «сегодня оружие нападения слабой стороны - это человек, и человек часто не личность, которая носит и использует оружие, а он сам является оружием, которое жертвует собой, чтобы уничтожить врага и он делает это потому, что убежден, что должен сделать это». Giuseppe Caforio, “The Asymmetric Warfare: In Search of a Symmetry," in Armed Forces and Conflict Resolution: Sociological Perspectives, ed. Giuseppe Caforio, Gerhard Kümmel, and Bandara Purkayastha (Bingley, U.K.: Emerald Group Publishing, 2008), 7-24.

16 "Palestinian Official: Women Must Martyr Themselves," WND.com (22 June 2007); доступно на: http://www.wnd.com/2007/06/42195/.

17 Richard Landes, "What Gilad Shalit Tells Us about the Respect for Life in Europe, Israel, and Palestine," The Telegraph (U.K.) (21 October 2011); доступно на: www.telegraph.co.uk/ comment/personal-view/8841737/What-Gilad-Shalit-tells-us-about-the-respect-for-life-inEurope-Israel-and-Palestine.html. 
ламского конгресса Канады, заявил, что каждый израильтянин возраста старше восемнадцати лет является законной целью для палестинских террористических атак: «Каждый старше восемнадцати является частью армии». ${ }^{18}$

Один из риторических приемов, применяемых в этих призывах к джихаду, состоит в том, чтобы поощрять мусульман жертвовать собой и в то же время представлять свою сторону объектом угрозы со стороны врагов (старый трюк идеологической пропаганды в конвенциональных конфликтах). Как заявлял Бен Ладен, взывая к джихаду против «Евреев и крестоносцев» в 1998 году, «Убивать американцев и их союзников - гражданских и военных - является индивидуальной обязанностью каждого мусульманина, который может делать это в любой стране, где только возможно, чтобы освободить мечеть Ал-акса и священную мечеть [Мекку] от власти неверных и чтобы выгнать их армии из всех исламских земель побежденными и неспособными угрожать ни одному мусульманину». ${ }^{19}$ В этом изложении утверждается, что насильственный джихад необходим для защиты от экзистенциальной угрозы, которую представляют для мусульманского мира западные армии и марионеточные режимы, получающие их поддержку.

Многие считают, что Тигры освобождения Тамил-Илама (ТОТИ), сепаратистская группа на Шри-Ланке, были первыми, кто использовал самоубийственные взрывы как террористическую тактику. В конструирование своей идеологии они позаботились вложить элементы, которые помогли бы мотивировать самоубийц и оправдать массовые убийства. Как доказывает шведский антрополог и эксперт по культуре мучеников ТОТИ:

Тамильские политики использовали религиозные сионистские понятия, чтобы описать преданность идее создания тамильской нации. Использование религиозных терминов, конечно, не является редкостью в мировой практике. Политики часто говорят о «жертвах» во имя нации. Из этих терминов нельзя выжать много пользы, все-таки они часть политической риторики. В случае с ТОТИ, однако, мы находим целую систему технических религиозных терминов, что-то вроде репертуара, который был создан после систематического исследования членами Комиссии по великим героям ТОТИ. На самом деле существует специальная комиссия в каком-то доме в Ялпанаме, предназначенная для создания героической символики и концепций. Они являются частью усиления идеологического сопротивления и мобилизации - наряду с усилением военного сопротивления ... ТОТИ предлагает идею кyтантирам, «независимости» предполагаемого государства, известного как Тамилилам, и эта кутантирам является «священной» целью, что-то вроде Сиона для

18 Quoted in "Muslim Leaders' Statements Affirm National Post's Position," HonestReportingCanada (27 October 2004); доступно на: http://www.honestreporting.ca/news_article_name/ 765432antiarab.aspx.

19 Osama bin Laden, "Jihad Against Jews and Crusaders: World Islamic Front Statement," 23 February 1998; доступно на: www.fas.org/irp/world/para/docs/980223-fatwa.htm. 
ТОТИ. Эта идея находится в самом центре ТОТИ как политического движения с религиозными устремлениями. ${ }^{20}$

Другим политическим актором на поле асимметричной войны, который создал свою особенную идеологию, было японское движение Аум Синрике. Действительно, как констатирует Эндрю Пратт, «Культ Аум Синрике, который был переименован на Алеф, представлял собой наиболее смертельную манифестацию апокалипсической религиозной секты Новой эры. Аум сочетал положения буддизма, индуизма и христианства и был одержим апокалипсисом .... Группа попала в заголовки мировых СМИ, когда 20 марта 1995 года ее члены совершили нападение в токийском метро, используя химические вещества». ${ }^{21}$

\section{Конкретные акты}

Мусульмане должны обучать своих детей Джихаду и ненависти кевреям, христианам и неверным.

Саудовский проповедник Шейх Мухаммад Салих аль-Мунаджид ${ }^{22}$

Отправной точкой для любого идеологического фундаментализма является обучение и индоктринация молодого поколения. Исламский фундаментализм, к примеру, реализует этот процесс через исламские религиозные школы, или медресе, которые во многих смыслах являются для молодых людей единственной возможностью, которой они располагают, получить какое-нибудь культурное образование. $^{23}$

Число этих школ увеличивалось экспоненциально со временем. Данные о Пакистане показывают, что если в 1947 году во всей стране было 137 медресе, то в 1994 их число выросло до 2500 в одной только провинции Пенджаб. В 2002 году «Пакистанский министр по делам религий др. Махмуд Ахмад Гази оценил их число в 10 000, признав, что существует проблема с определением, что считать медресе, и поэтому вполне возможно, что их число больше. В этих школах учатся, по крайней мере, в течение определенного срока, от одного до 1.7 миллиона уче-

20 Peter Schalk, "Historization of the Martial Ideology of the Liberation Tigers of Tamil Eelam (LTTE)," South Asia: Journal of South Asian Studies 20 (1997): 1-38.

21 Pratt, "Terrorism's Evolution," 25.

22 "Saudi Education System Majors in Jihad," WND.com (24 December 2002); доступно на: www.wnd.com/2002/12/16394/.

23 «Медресе - это школы, где изучается Коран и которые предоставляют бесплатное религиозное образование, проживание и питание, и по существу, это школы для бедных. Около трети детей, которые ходят в школу в Пакистане, посещают медресе. Большинство учеников находятся в возрасте от 5 до 18 лет. Медресе предназначены для введения мусульманских детей в основные положения Корана, пропаганды исламской этики в обществе и подготовки учеников к выполнению религиозных обязанностей. Врагом номер один для них является секуляристское образование и священнослужители, которые их контролируют. Медресе всегда успешно противодействовали попыткам правительства их реформировать». Смотри: CeMiSS Quarterly 3:2 (Summer 2005). 
ников». ${ }^{24}$ С конца 1970-х эти коранические школы, число которых многократно увеличилось в племенных областях на границе с Афганистаном, создали огромный резерв молодых добровольцев джихадистов, являющихся определяющим фактором для исламского радикализма в Пакистане.

Деятельность медресе, направленная на обучение их учеников в духе фундаментализма и джихада, подтверждается многочисленными примерами. К примеру, обыск в 2012 году в медресе Джамия Дарул Улуум Исламия «обнаружил наличие 10 мешков с взрывчаткой, каждый весом в 50 килограмм». ${ }^{25}$

Идеологическая подготовка молодых людей, проводимая в медресе, сопровождается пропагандой и политико-религиозной индоктринацией масс, которые слабая сторона в конфликте осуществляет посредством использования всех инструментов для коммуникации, которые их враг, более сильная сторона, создала в процессе строительства информационного общества. ${ }^{26}$ Примеры этой деятельности можно найти в выпуске таких изданий, как англоязычный журнал Inspire, предназначенный для единоверцев, проживающих на территории более сильной стороны, который поощряет своих читателей совершать нападения в странах, где они живут. Исламистские группы также используют коммуникационные возможности Интернета, создавая такие веб-сайты, как Al-Neda (Зов, закрытый в 2002 году), который был разработан как основной онлайновый информационный центр Аль-Каиды для публикации идеологических трактатов и заявлений и который администрировался из Саудовской Аравии Юсуфом аль-Айири, сторонником Усамы Бен Ладена. Они так же организовали медийные издания в странах Запада, такие как блоги для целей пропаганды и прозелитизма, как было документировано итальянской газетой Il Sole 24 Ore, которая писала:

Прокуратура города Кальяри распорядилась заблокировать доступ к сайтам, предположительно используемым для разжигания исламского терроризма. Распоряжение, с которым ознакомилась газета Il Sole 24 Ore, закрывало сайты:

blog.libero.it/islamnuri, blog.libero.it/islamitalia, ummusama.wordpress.com, islamo-il-monoteismo.over-blog.com and abulbarakat.wordpress.com ...

По мнению отдела по общим расследованиям и специальным операциям полиции города Кальяри, расследуемые лица, «члены исламской фундаменталистской группы», использовали эти сайты для распространения «религиозных пропагандистских материалов, подстрекающих к актам насилия» и получения «информации и документов по изучению военных умений для террористических целей», таких как «изготовление и использование взрывчатки, огнестрельного и другого оружия». ${ }^{27}$

24 Там же.

25 "Counter-terrorism: SSP-linked Madrassa Raided by Agencies," The Express Tribune (Pakistan) (22 March 2012); доступно на: http://tribune.com.pk/story/353428/counter-terrorismssp-linked-madrassa-raided-by-agencies/.

26 В асимметричной войне значение использования средств коммуникации и особенно новых информационных и коммуникационных технологий переводит существенную часть военной конфронтации с традиционного «поля боя» в сферу конфронтации в СМИ.

27 Il Sole 24 Ore (24 April 2012). 
В связи с таким использованием мировой сети, журнал Jane's писал: «Растут опасения, что Интернет заменил афганские тренировочные лагеря в качестве основного полигона для начинающих джихадистов. Огромная библиотека информации об изготовлении бомб, оружия и о тактике нападения теперь доступна в режиме онлайн». ${ }^{28}$

Идеологическая подготовка и индоктринация начали давать результаты еще в 1983 году, когда были совершены первые большие самоубийственные нападения, в том числе:

- 18 апреля 1983, Бейрут, Ливан: Разрушено посольство США при самоубийственном взрыве заминированной машины, погибли 63 человека, в том числе 17 американцев. Ответственность на себя взяла группа Исламский джихад.

- 23 октября 1983, Бейрут, Ливан: Шиитские террористы-смертники взорвали грузовик рядом с военными казармами США в аэропорту Бейрута, убив 241 морских пехотинцев. Через несколько минут взрыв второй бомбы привел к гибели 58 французских парашютистов в казарме в Восточном Бейруте.

- 12 декабря 1983, Кувейт Сити, Кувейт: Шиитские террористы на заминированных грузовиках атаковали посольство США и другие цели, погибли пятеро и были ранены восемьдесят человек.

Террористические нападения с использованием взрывных устройств, часто переносимые и детонируемые боевиками, которые хотят совершить самоубийство, становятся все более частым явлением в последующие годы и начинают распространяться на гораздо более уязвимые цели, такие как авиалайнеры. Здесь мы вспоминаем нападение 21 декабря 1988 года над Локкерби, Шотландия, когда на-

28 “Finding Nemo: Profile," Jane's Terrorism and Security Monitor (4 July 2008); доступно на: http://articles.janes.com/articles/Janes-Terrorism-And-Security-Monitor-2008/Finding-

Nemo.html. Матт Армстронг в своих работах по афганскому театру операций приводит интересный пример средств, используемых слабой стороной в той несимметричной войне: «Веб-сайт с наименованием бывшего режима - Исламский Эмират Афганистана - используется как международный центр для распространения заявлений лидеров и хвастливых рассказов о подвигах на поле боя. Хотя все и примитивно, но объем работы вовсе не маленький; информация обновляется по нескольку раз в день на пяти языках. Журналы, издаваемые движением или его сторонниками, обеспечивают другой источник информации о структурах руководства и по вопросам, которые считают важными. Но в основном из-за неграмотности сельского населения прилагаются большие усилия для распространения проповедей и военных сводок на DVD-дисках, аудиокассетах, шабнама («ночные письма», памфлеты или листовки, обычно содержащие угрозы) и традиционных националистических песен и поэм. Талибы все чаще используют сотовые телефоны для распространения своих сообщений». Зрелое использование «глобализационных» процессов здесь очевидно. Matt Armstrong, "The Art of Asymmetric Warfare," MountainRunner.us (28 July 2008). 
правляющийся в Нью-Йорк самолет компании Пан Ам, Боинг 747, взорвался в воздухе от террористкой бомбы и упал на шотландскую деревню, унося жизнь всех 259 пассажиров на борту и 11 человек на земле. Среди пассажиров были 45 студентов Университета Сиракузы и много американских военных. Спустя пятнадцать лет, в августе 2003 года, Ливия признала свою ответственность и предложила 2.7 миллиарда долларов США в качестве компенсаций семьям погибших.

Использование террористов-смертников позже распространилось и на корабли. 12 октября 2000 года оперативники Аль-Каиды в Йемене совершили самоубийственное нападение на заминированном корабле, причинив существенные повреждения военному кораблю США, эсминцу Коул, также погибли и 17 моряков. Или до этого, 7 октября 1994 года, в Средиземном море стрелок, связанный с Ливией, напал на итальянский круизный корабль Achille Lauro, убив одного туриста из США.

Использование террористов-смертников было и остается широко распространенным оружием слабой стороны в асимметричных конфликтах по всему миру. Чтобы дать конкретное представление о характере этих нападений, в следующем параграфе приводится описание одного самоубийственного покушения, совершенного инноваторами этого метода, ТОТИ на Шри-Ланке:

\begin{abstract}
Взрыв в Центральном банке был одним из самых смертоносных террористических нападений, совершенных ТОТИ во время сепаратистской гражданской войны в Шри-Ланке между правительством и тамильскими тиграми. Нападение произошло 31 января 1996 года в городе Коломбо в Шри-Ланке. Грузовик (42-6452), нагруженный 440 фунтами мощной взрывчатки, прорвался через центральные ворота Центрального банка, высотного здания на набережной, в котором осуществлялось большинство финансовых операций в стране. Пока один из террористов вел перестрелку с охраной, террорист-смертник в грузовике сдетонировал мощное взрывное устройство, которое разрушило банк и повредило восемь других зданий поблизости. За грузовиком следовал трехколесный мотоциклет с двумя боевиками ТОТИ, вооруженными автоматическими винтовками и пусковой установкой РПГ.

Взрыв привел к гибели 91 человека, а 1400 других получили ранения. По крайней мере 100 человек потеряли зрение. Среди раненых были два гражданина США, шестеро японцев и один датчанин. Большинство пострадавших были прохожие или посетители маленьких магазинов рядом с банком. ${ }^{29}$
\end{abstract}

Эскалация террора продолжалась, и ее кульминацией стало использование угнанных самолетов в качестве оружия массового уничтожения. Как все знают, 11 сентября 2001 года террористы Аль-Каиды врезались на двух пассажирских реактивных самолетах в башни-близнецы Центра мировой торговли в Нью-Йорке; еще два угнанных реактивных самолета ударились в здание Пентагона в Арлингтоне, штат Вирджиния, и разбились на поле в деревенской местности в Пенсильвании недалеко от города Шанксвилль. Общее число погибших и пропавших без вести достигло 2992: 2749 в Нью-Йорке, 184 в Пентагоне, 40 в Пенсильвании и 19 тер-

29 “Central Bank bombing,” Wikipedia.org; доступно на: http://en.wikipedia.org/wiki/Central_ Bank_bombing. 
рористов. 20 февраля 2009 года Тигры Тамила попытались повторить эту схему, организовав самоубийственный воздушный рейд на военные объекты, расположенные внутри и вокруг Коломбо. Однако эти нападения провалились, так как военно-воздушные силы Шри-Ланки сбили нагруженные взрывчаткой самолеты до того как они достигли своей цели.

Этими терактами полностью была достигнута цель перенести войну на территорию более сильной стороны. Эта цель была подтверждена и более поздними и значительными актами, такими как террористические атаки на гражданские цели, совершенные на острове Бали 12 декабря 2002 года, 23 октября 2002 в Москве, 11 марта 2004 в Мадриде, 1 сентября 2004 в Беслане, в июле 2005 в Лондоне и 26 ноября 2008 в Мумбае. Объектами этих нападений были людные места в государствах сильной стороны (торговые центры, большие гостиницы, железные дороги, метро, дискотеки, рестораны, школы), в особенности уязвимые транспортные средства (самолеты и аэропорты), туристические группы, посольства, объекты Объединенных Наций, правительственные помещения, казармы и жилищные районы, но так же и отдельные личности, часто выбранные для похищения или убийства из-за их символического значения.

Таким был случай с датским режиссером Тео ван Гогом, убитым 2 ноября 2004 года, а также те похищения, которые были совершены с целью получения выкупа или для обмена на заключенных, и которые часто заканчивались трагически, как случилось 11-19 июня 2004 в Рияде, Саудовская Аравия, когда террористы похитили и экзекутировали Поля Джонсона младшего, убив двух других американцев и оператора ВВС при нападении с использованием огнестрельного оружия. 26 апреля 2010 года террорист-смертник из АКАП напал на эскорт британского посла в столице Йемена, Сана. Были ранены двое сотрудников охраны и один прохожий, но посол не пострадал. И последнее, в мае 2012 года член Высшего совета мира в Афганистане, Арсалан Рахмани Даулат был застрелен из пистолета с глушителем по дороге на работу в Кабуле. Как и в случае террористов-смертников, исламистские группы следовали примеру Тигров Тамила, которые достигли наиболее зрелищного успеха в политическом покушении 21 мая 1991 года, когда боевик ТОТИ убил премьер-министр Индии, Раджива Ганди, в Тамил Наду, после чего, окруженный полицией, застрелился. Похищения также совершаются в пропагандистских целях, как в случае с гражданами западных стран, которые были похищены в Афганистане и Пакистане исламистскими террористами и которые показали в прямом эфире, как их заложники читают предварительно подготовленные заявления, осуждающие политику Запада.

Конкретные акты слабой стороны в асимметричном конфликте дополняются «горячими» военными и/или партизанскими действиями там, где географические, политические и социальные условия это позволяют. Главным примером является Афганистан, где с 2001 по 2011 год потери коалиционных сил (сильной стороны) составили 2765 убитых. 


\section{Используемые инструменты}

Как уже упоминалось, информационные и коммуникационные технологии, предоставляемые сегодня информационным обществом, являются инструментами, которые слабая сторона в асимметричном конфликте искусно использует в свою пользу. ${ }^{30}$

На первом месте это мировая сеть Интернет. Габриель Вейманн пишет:

По своей природе Интернет по многим показателям является идеальной ареной для деятельности террористических организаций. Прежде всего он предоставляет

- Легкий доступ;

- Частичное или полное отсутствие регуляции, цензуры или других форм государственного контроля;

- Огромную потенциальную аудиторию, распределенную по всему миру;

- Анонимность коммуникации;

- Быстрый поток информации;

- Невысокие расходы на подготовку и поддержку присутствия в сети;

- Мультимедийную среду (возможность сочетать текст, графику, аудио- и видеоматериалы, а также возможность для пользователей скачивать фильмы, песни, книги, постеры и т.д.);

- Возможность формировать отражение своей информации в традиционных СМИ, которые все чаще используют Интернет как источник для сюжетов. ${ }^{31}$

К этому можно добавить использование традиционных медиа, чье значение как средство в войне, очевидно, полностью осознается лидерами фундаменталистских движений. Как писал Айман аль-Зауахири в июле 2005 года: «Мы участвуем в

30 Коммуникационные технологии, доступные сегодня (в особенности информационные и коммуникационные технологии), предоставляют этим группам большой спектр новых инструментов, позволяя широкую пропаганду и информацию с использованием Интернета; надежные широко охватывающие связи (мобильные телефоны и электронная почта); осуществление подготовки для применения партизанских способов военных действий и террористических тактик путем распространения DVD дисков. Смотри: Giuseppe Caforio, "The Information Society and The Changing Face of War," in Society, Culture and Technology at the Dawn of the $21^{\text {st }}$ Century, eds. Janusz Mucha and Katarzyna Lesczczynska (Newcastle upon Tyne, U.K.: Cambridge Scholars Publishing, 2010), 129-42. И все это возможно потому, что «Демократия предоставляет идеальные основные условия для терроризма. ... В частности, эфирные СМИ и Интернет позволяют террористам расти как раковая опухоль в комфортном пространстве, созданном свободой, которую обеспечивает демократия - той самой свободой, которую террористы хотят запретить». «Растущая глобализация СМИ и спутниковой связи», продолжает Бокстетт, «как и быстрое развитие Интернета расширило спектр потенциальной аудитории террористов. ... Симбиотическая взаимосвязь между террористическими событиями и медиа является очевидной; преступники имели бы гораздо меньшее влияние без публичности, которую обеспечивают СМИ и едва ли можно ожидать, что медиа будут воздерживаться от репортажей об актах терроризма». Carsten Bockstette, "Taliban and Jihadist Terrorist Use of Strategic Communication," Connections: The Quarterly Journal 8:3 (Summer 2009): 13.

Weimann, "How Modern Terrorism Uses the Internet." 
сражении, и больше половины этого сражения происходит на поле битвы СМИ. ... Мы участвуем в медийной войне за умы и сердца наших Уммах». $^{32}$ В другом исламистском журнале было написано: «Снимайте все; это хороший совет для всех моджахедов. ... Вы должны понимать, что каждый кадр, заснятый вами, так же хорош, как снаряд, выпущенный по крестоносному врагу и его марионеткам». ${ }^{33}$

Для Аравийского полуострова мы располагаем интересным локальным примером того, как использует СМИ слабая сторона, и который был опубликован в журнале Jane's:

Значение эффективной пропаганды было осознано исполнителями Аль-Каиды в регионе еще в начале кампании. В 2003 и 2004 годах первоначальная организация АКАП в Саудовской Аравии издавала два онлайн-журнала: Muaskar al-Battar (Tpeнировочный лагерь Al-Battar), который был сфокусирован на выбор целей, на тактику и вооружение; и Sawt al-Jihad (Голос Джихада), который занимался вопросами идеологии. Эти издания сопровождались письменными заявлениями, посылаемыми на веб-сайты, когда организация принимала на себя ответственность за террористические нападения, и иногда видеоклипами.

В июле 2010 года АКАП начала издавать журнал на английском языке, названный «Inspire». Последний, седьмой номер вышел в октябре 2011 года. Inspire пытается подстрекать низовых джихадистов, живущих в западных странах. Журнал добивается этого, объявляя, что начинающие джихадисты могут исполнять важную роль в ослаблении западных сил; восхваляя задержанных низовых джихадистов как героев, даже если их попытки совершить нападения были совсем любительскими; подбрасывая идеи для выполнения простых нападений, таких например, как взрыв автомобилей, начиненных металлическими лезвиями, чтобы ранить больше прохожих; предоставляя инструкции для изготовления элементарных импровизированных взрывных устройств (ИВУ) из легко доступных веществ. Примерами людей, разрекламированных журналом Inspire, являются Рошонара Чаудари, который ударил ножом и ранил члена британского парламента в мае 2010 года, и Таймур Абдульвахаб аль-Абдали, террорист-смертник, который совершил самоубийство в Стокгольме в декабре 2010 года. ${ }^{34}$

Тигры Тамила тоже создали свою собственную систему коммуникации и пропаганды, доходя до развертывания собственной спутниковой телевизионной сети, которая вещала на всю Азию и Ближний Восток. ${ }^{35}$

Широко используются телевизионные клипы и декларации террористов, зачитанные перед самоубийственными взрывами. Эти клипы с помощью мобильных команд, оборудованных DVD-проигрывателями, достигают до самых отдаленных

32 Craig Whitlock, "Keeping Al-Qaeda in His Grip: Al-Zawahiri Presses Ideology, Deepens Rifts Among Islamic Radicals," Washington Post (16 April 2006); доступно на: www.washingtonpost.com/wp-dyn/content/article/2006/04/15/AR2006041501130 pf.html.

33 "Internet Jihad: A World Wide Web of Terror," The Economist (12 July 2007); доступно на: http://www.economist.com/node/9472498.

34 "Al Qaeda in the Arabian Peninsula," Jane's World Insurgency and Terrorism (5 April 2012).

35 Kasun Ubayasiri, "Velupillai Prabakaran, Leader of Tamil Eelam: An Elusive Leader's Annual Speech," paper published by Central Queensland University, 2006; доступно на: http://tamilnation.co/ltte/vp/mahaveerar/06ubayasri.htm. 
деревень, далеко за пределами покрытия телевизионных сетей. Интересно отметить, что согласно репортажам журнала Jane's об Аравийском полуострове, заявления отдельных боевиков перед тем, как они себя взорвут, это не обязательно их собственные слова, а чаще всего слова, заранее написанные персоналом медиа-отдела.

Другой способ напрямую контролировать СМИ, это создать собственную медиа. Это может быть газета, журнал, радиостанция, а в некоторых случаях террористы создавали даже свои собственные телевизионные каналы, вещающие через спутник на миллионы домов по всему свету, как сделали Тигры Тамила (смотри выше). Лучшим примером является спутниковый канал Al-Manar ливанского движения «Хезболлах». Al-Manar напрямую распространяет точку зрения «Хезболлах», и даже очень успешно. В действительности считается, что он входит в пятерку самых популярных телевизионных каналов на Ближнем Востоке, а в международном плане этот канал смотрят десять миллионов зрителей в день. ${ }^{36}$

Но до создания террористами современных СМИ основными инструментами в их стратегическом арсенале являлись взрывчатые вещества, используемые в разных формах: от террористов-смертников, которые надевают пояс, начиненный взрывчаткой, до более часто используемых легковых или грузовых машин, заминированных ТНТ, заминированных катеров, бомб-посылок, отправленных почтой или грузовым самолетом, ИВУ, спрятанных на дороге. Нет необходимости приводить здесь другие примеры взрывов или случаи с террористами-смертниками, так как многочисленные примеры были показаны выше. Однако стоит вспомнить три особых и, может быть, менее известных случая:

- 1 сентября 1992 года, Саиндамару, Калмунай, Шри-Ланка: взрывное устройство ТОТИ, прикрепленное к велосипедной тележке для продажи мороженого взорвалось на рынке, 22 человека убито и 77 ранено.

- 29 октября 2010: два ИВУ, посланных из Йемена в Чикаго через международную курьерскую компанию, были перехвачены в Объединенном Королевстве и в Объединенных Арабских Эмиратах. Устройства были замаскированы под безобидные упакованные кассеты для лазерных принтеров и были адресованы двум синагогам в Чикаго.

- 17 января 2011, Спокейн, шт. Вашингтон: взрывное устройство в виде трубы было обнаружено на маршруте шествия в день памяти Мартина Лютера Кинга. Бомба, «грамотно сделанное устройство», которое должно было поразить участвующих в марше шрапнелью, причиняя многочисленные жертвы, было обезврежено и никто не пострадал.

Террористы показали, что они в состоянии использовать для своих целей взрывные устройства любой конструкции. Они не пренебрегают использованием и химического оружия. Единственная причина, по которой использование такого

36 Смотри: Avi Jorisch, Beacon of Hatred: Inside Hizballah's al-Manar Television (Washington, D.C.: Washington Institute for Near East Policy, 2004). 
вида оружия остается ограниченным, связана с трудностями в обращении с ним. Пример редких случаев успешного применения имел место в Японии в 1995 году, когда религиозная секта Аум Синрике выпустила газ зарин в токийском метрополитене. Погибли 30 человек и пострадали более 5000. Это нападение было кульминацией серии из восьми нападений, которые группа совершила в течении двадцати одного месяца.

При террористических нападениях часто применяется и легкое стрелковое оружие, но такое оружие обычно наносит ограниченный вред, поэтому оно считается менее подходящим для привлечения общественного внимания. По этой причине оно не является излюбленным средством в террористическом арсенале, который содержит огромное разнообразие инструментов для совершения убийств и для запугивания, начиная с ножей и кончая бульдозерами. Эти и все другие инструменты, которые может произвести на свет человеческая изобретательность в мире, свободном от моральных ограничений, были использованы и используются слабой стороной в асимметричном конфликте.

В ситуации, где нет четких границ между асимметричной войной и организованной преступностью, торговцы оружием и взрывчатыми веществами без проблем поставляют инструменты причинения смерти тем, кто готов за них заплатить. Антонио Мария Коста, исполнительный директор управления ООН по борьбе с наркотиками и преступностью, в этой связи в ноябре 2005 года прокомментировал:

Я считаю, что терроризм, даже когда он мотивирован политически, нельзя отделить от преступности. ... Хотя в своих крайних проявлениях эти два рода деятельности и отличаются, их связывает большая серая зона. Запугивание с применением насилия является традиционным необходимым условием (modus operandi) функционирования организованной преступности. Преступники иногда надевают идеологическую мантию террористов, тогда как действия многих террористов в конечном итоге определяются чаще алчностью, чем политикой. В реальной жизни борьба с одним из этих зол часто эквивалентна борьбе с другим. ${ }^{37}$

Способность террористов платить обеспечивается тем, что сейчас называют теневой экономикой терроризма. Как я писал в другом месте:

Сопутствующий феномен, который несколько авторов ... называют «тени войны», является экономической основой существующих форм войны, охватывая весь мир от больших городов до отдаленных деревень, во время войны и во время мира. Незаконная торговля бриллиантами, древесиной, наркотиками, оружием, автомобилями, рабочей силой и т.д. имеет те же теневые стороны, что и нелегальная продажа отпускаемых по рецепту лекарств, азиатского программного обеспечения, контрафактных продуктов и одежды. ...

Новые формы военных действий порождают на практике новый тип экономики, основанный на насилии. Деньги собираются путем грабежа, мародерства, продажи наркотиков и алкоголя, контрабанды сигарет, организации нелегальной иммигра-

37 Jane's Intelligence Review (17 February 2006). 
ции, принуждения законных иммигрантов выплачивать преступникам часть своего заработка, присваивания части международной гуманитарной помощи. По мнению некоторых исследователей, ... новые войны можно рассматривать как главный источник неофициальной глобальной экономики, т.е. транснациональной преступной экономики, которая является темной стороной глобализации. ${ }^{38}$

Идеологизация борьбы прибавляет к этим формам и другие возможности для финансирования, которые можно назвать возможностями «исправной веры». К примеру, журнал Jane's сообщает, что:

АКАП финансирует свою деятельность, главным образом используя два механизма.
Первый, это так называемый закат, или филантропические пожертвования, соби-
раемые связанными с АКАП активистами. Второй, это взимаемые мечетями сборы,
хотя в некоторых больших мечетях Саудовской Аравии этот процесс в некоторой
степени отрегламентирован. И при том, и при другом механизме все взносы дела-
ются наличностью. Хотя некоторые из доноров могут знать, как расходуются их
деньги (так называемые «паркетные боевики»), большинство из них верит, что их
пожертвования используются для исламской благотворительности. ${ }^{39}$

Конечно, использование заката для финансирования исламских террористических групп имеет место не только на Аравийском полуострове. Приобретение вооружения и взрывчатки облегчается наличием оружейных рынков, которые возникли повсеместно после окончания холодной войны и распада Советского Союза. Большая часть оружия, которое можно приобрести на этих базарах под открытым небом, приходит из России и Китая, хотя часть проделывает свой путь на Ближний Восток с Балкан.

\section{Принятые стратегии ${ }^{40}$}

Стратегии, которые использует более слабая сторона в асимметричных конфликтах, становятся все более глобальными. К примеру, постоянным элементом стра-

38 Giuseppe Caforio, "The Military Profession and Asymmetric Warfare," in New Wars, New Militaries, New Soldiers: Conflicts, the Armed Forces and the Soldierly Subject (Vol. 19 in Contributions to Conflict Management, Peace Economics and Development), ed. Gerhard Kümmel and Joseph Soeters (Bingley, U.K.: Emerald Group Publishing, 2012), 8-13. Смотри так же: Mary Kaldor, New and Old Wars: Organized Violence in a Globalized Era (London: Polity Press, 2001); David Kilcullen, The Accidental Guerrilla: Fighting Small Wars in the Midst of a Big One (Oxford: Oxford University Press, 2009).

39 "Al Qaeda in the Arabian Peninsula."

40 Нетрудно заметить существование новых аспектов войны в двадцать первом веке. Эти новые формы военных действий, похоже, характеризуются преобладающе политической и идеологической (часто религиозной) природой, упорными усилиями использовать медиа и сознательным и целенаправленным пренебрежением этических норм ведения войны. Стратегия состоит в том, чтобы добиваться политической власти вселением страха и ненависти, созданием климата террора, устранением умеренных голосов и отрицанием терпимости. Смотри: Caforio, "The Asymmetric Warfare: In Search of a Symтеtryл" 
тегии слабой стороны в асимметричных конфликтах, похоже, является изолирование основного противника (в нынешней ситуации войны с терроризмом, это Соединенных Штатов) от его союзников. Интересный пример этой стратегии дает документ, опубликованный на радикально исламистском веб-сайте, о котором сообщает Карстен Бокстетт, и который гласит: «Мы думаем, что испанское правительство не вынесет больше, чем два, максимум три удара, после чего ему придется уйти из-за общественного давления. Если после этих ударов войска все еще останутся в Ираке, тогда победа социалистической партии почти обеспечена и вывод испанских сил войдет в их предвыборную программу». ${ }^{41}$ Насколько нам известно, как раз это и случилось в Испании после взрывов на транспорте в Мадриде в 2004 году.

Коммуникация так же должна быть глобальной. Лидеры движений слабой стороны на деле демонстрируют осведомленность о значении СМИ в развитии стратегий борьбы, как уже было показано в параграфе об использовании инструментов. Это борьба, которая редко остается ограниченной в рамках того региона или государства, где она началась, но чаще всего переносится на международный уровень с помощью различных инструментов и процедур. К примеру, турецкие джи$x a d u c m b l$ все больше обращаются к Интернету, чтобы добраться до глобальной аудитории:

Хотя арабский язык остается доминирующим в Интернет-деятельности джихадистов, в последние годы наблюдается очевидный рост числа радикально исламистских веб-сайтов и дискуссионных форумов на турецком языке. Большинство симпатизантов джихадистов живет в Турции, хотя теперь есть веб-сайты, которые, похоже, в основном предназначены для этнических турков, живущих в Западной Европе, в особенности для приблизительно трех миллионов человек, проживающих в Германии и говорящих на турецком. ${ }^{42}$

Похоже, наиболее значимый союзник АКАП, это сомалийская группа Ал Шабаб. Обе организации сделали заявления, выражающие взаимную поддержку, а также известно, что йеменские джихадисты сражаются в Сомали. В таких заявлениях часто подчеркивается значение единства в уммах (глобальном мусульманском сообществе). ${ }^{43}$

То, что обращение к технологиям асимметричной войны стало излюбленным выбором слабой стороны при любых обстоятельствах, подтверждается прошлыми и недавними событиями далеко за пределами Ближнего Востока. В 2008 году агенты китайского правительства арестовали членов двух террористических групп в Синьцзянь-уйгурском автономном районе Западного Китая по подозрению в том, что группы, состоящие из этнических тюркских сепаратистов, планировали

41 Bockstette, "Taliban and Jihadist Terrorist Use of Strategic Communication," 7.

42 “Turkish Jihadis Go Online," Jane's Terrorism and Security Monitor (26 March 2009).

43 "OSINT Summary: AQAP Reaches out to Affiliate Organisations in Africa," Jane's Terrorism and Security Monitor (24 May 2012). 
саботажи Олимпийских игр в Пекине. ${ }^{44}$ В Индии, одновременно с подъемом исламистского терроризма, постоянно расширяет свой масштаб и возможности маоистское движение. Эта группа разрослась настолько значительно, что в 2007 году премьер-министр Манмохан Сингх охарактеризовал маоистов как «самую большую проблему внутренней безопасности, стоящую перед Индией». ${ }^{45}$ Восстание против режима Ассада в Сирии в 2012 году так же имело некоторые характерные особенности, присущие партизанским движениям в Ираке и других местах, в том числе и использование ИВУ и заминированных машин. В этих случаях мы видим, что даже революционное движение, являющееся внутренним для данной страны, когда оно сталкивается с мощью государственного аппарата, для продолжения борьбы прибегает к средствам терроризма.

Стратегия слабой стороны так же включает попытки подорвать экономику тех стран, где ведется борьба, такими средствами как саботажи на объектах промышленности, особенно добывающей, так и ударами по туризму, который часто является главным источником дохода таких стран. Примерами попыток саботировать производство являются действия ячеек Аль-Каиды в Саудовской Аравии, которые фокусируют свои удары на военных формированиях США, находящихся в стране, а также на западных гражданах и других экспатриантах, работающих в нефтяной промышленности. Примерами нападений второго вида являются самоубийственные взрывы, направленные против туристических групп в Йемене. 2 июля 2007 года террорист-смертник взорвал заминированную машину у храма Савской царицы. Погибли восемь испанских туристов и два гражданина Йемена. 15 марта 2009 года террорист-смертник убил четверых южно-корейских туристов и их йеменского гида; через три дня после этого нападения последовал самоубийственный взрыв, направленный против приехавших родственников жертв первого

44 “OSINT Update: China Rounds up 'Olympics Terrorism Conspirators'," Jane's Terrorism and Security Monitor (9 May 2018).

45 "Red Storm Rising: India's Intractable Maoist Insurgency," Jane's Intelligence Review (15 May 2008). В этой связи Час Моррисон писал: «Давно существующий в Индии экстремизм левого толка привел к гибели, травмам или потери крова тысячи людей, что обычно остается незамеченным западными теоретиками. Многие академические исследования, касающиеся революций, терроризма и гражданской войны, вообще не упоминают о наксалитах. Наксалитский конфликт был бы гораздо более известным, если бы внимание международного сообщества не было настолько приковано к событиям на границе между Пакистаном и Афганистаном, или если бы среди жертв были иностранцы. Восстание началось в городе Наксалбари в штате Западная Бенгалия, поэтому повстанцы более известны как «наксалиты» (как синоним терминов «маоисты», «повстанцы», «боевики»). Хотя существуют только приблизительные оценки числа комбатантов, Би-Би-Си считает, что в районе действуют от 10000 до 20000 вооруженных наксалитов». Morrison, "Grievance, Mobilisation and State Response: An Examination of the Naxalite Insurgency in India," Cesran International (23 May 2012); Доступно на: http://cesran.org/index.php?option=com_content\&view=article\&id=1456\%3Agrievancemobilisation-and-state-response-an-examination-of-the-naxalite-insurgency-inindia\&catid $=65 \% 3$ Amakale-ve-raporlar $\&$ Itemid $=318 \&$ lang $=$ en. 
взрыва (ИВУ было спрятано в портативной стерео-аппаратуре). ${ }^{46}$ Эти нападения были совершены на фоне других, хорошо известных эпизодов, таких как массовые убийства туристов в Египте (в Луксоре 17 ноября 1997 года, когда погибли шестьдесят два человека; и на курорте Шарм эль-Шейх 23 июля 2005, когда погибли восемьдесят пять человек, в основном египтяне).

Современные технические возможности, необходимые для выполнения таких нападений, используются не только на одном театре или одной только фракцией. К примеру, по мнению журнала Jane's, «Террористы в Пакистане усвоили технологию удаленного прослеживания автомобилей и дистанционного детонирования заминированных машин. ... бомба может быть поставлена на машину без ведома собственника, выслежена с помощью GPS и системы мобильной связи и задействована текстовым сообщением тогда, когда машина приблизится к объекту». ${ }^{47}$ Нападения совершаются на объекты по всему миру, как свидетельствуют репортажи новостей из Нью Дели, Индия. В 2012 году камеры наблюдения засняли мотоциклиста, прикрепляющего магнитную бомбу к автомобилю, за рулем которого сидела супруга израильского дипломата. ${ }^{48}$

И последнее, техника вооруженных нападений развивается в соответствии с все более изощренной стратегией партизанской борьбы, как видно из заявления командира АКАП, Мухаммада аль-Ауфи, по саудовскому телевидению в начале 2009 года. Он сказал, что организация создаст лагеря в горах Йемена, откуда она сможет посылать saraya (ячейки) в саудовское королевство для идентификации подходящих объектов. Боевики потом будут возвращаться в Йемен для планирования нападений и получения одобрения руководства. Если получено разрешение, ячейки возвращаются для совершения нападений, после чего отходят обратно в Йемен, а другое подразделение приходит на их место в королевство. По мнению аль-Ауфи, стратеги АКАП считают, что эта кампания унизит Саудовские службы безопасности, которые будут не в состоянии реагировать, так как у АКАП практически не будет никакой сети в Саудовской Аравии, которую можно было бы уничтожить.

Как видно, обращение к средствам терроризма является только одной из форм борьбы слабой стороны в асимметричных конфликтах, хотя, может быть, и наиболее распространенной. Когда это возможно, группы слабой стороны так же предпринимают смертоносные нападения конвенционального типа или с использованием партизанской тактики. Уже упоминалось о нападениях и засадах против коалиционных сил в Афганистане, которые широко освещались в СМИ, но на местном уровне имеют место многие другие формы нападений, совершаемых боевиками в Афганистане, которые не привлекают внимания глобальных медиа. Джессика Снаппер очень точно уловила этот аспект асимметричной войны:

\footnotetext{
46 "Al Qaeda in the Arabian Peninsula."

47 “OSINT Update: Pakistani Terrorists Deploy Tracked Car Bomb," Jane's Terrorism and Security Monitor (9 May 2008).

48 “Shadow War between Iran and Israel Escalates," Jane's Defence Weekly (17 February 2012).
} 
Красота неконвенциональных способов боевых действий состоит в том, что хотя применяются непрямые и асимметричные методы, но так же используется и широкий спектр современных военных боевых способностей, которые могут подорвать мощь и влияние противника, несмотря на превосходство его конвенциональных технологий и инфраструктуры. В результате нерегулярные способы боевых действий наиболее эффективны при продолжительной борьбе, поскольку приводят к изнашиванию с течением времени решимости государства противника и его стратегических партнеров. ${ }^{49}$

АКАП, к примеру, в очередной раз показала свою способность совершать нападения с многочисленными жертвами 26 февраля 2012 года, когда в результате самоубийственного взрыва заминированного автомобиля в городе Мукалла в Йемене погибли двадцать шесть солдат республиканской гвардии. ${ }^{50}$ Немногим более чем через неделю, 4 марта, в череде нападений боевиков АКАП в городе Зинджибар и вокруг него были убиты 191 и похищены, по крайней мере, 73 солдата. Два отдельных ИВУ в автомобилях были взорваны в пригородах перед тем, как большая группа боевиков атаковала военную базу в нескольких километрах от города. Во время нападения на военную базу боевики АКАП захватили большое количество тяжелого вооружения, в том числе танк и несколько бронированных машин. ${ }^{51}$

\section{Выводы}

Существует множество теоретических работ и исследований по вопросам асимметричной войны, но цель этого исследования состоит в том, чтобы вернуть разговор к развитию, эволюции и нарастанию напряженности, а так же дать общую картину конкретной ситуации. ${ }^{52}$ Я считаю, что только детальное знание и понимание стратегий, используемых инструментов, разнообразия примеров и этических оснований могут дать целостное видение этого феномена. Наша ментальность как жителей развитых, промышленных стран, делает затруднительным для нас следование логике того мира, где отчаяние, реваншизм и идеология сливаются, чтобы породить этические ценности (которые для нас являются анти-ценностями) и по-

49 Jessica Snapper, "Hezbollah Bolsters Irregular Warfare Capabilities," JessicaSnapper.com (17 Мау 2012); доступно на: http://jessicasnapper.com/2012/05/17/hezbollah-bolsters-irregularwarfare-capabilities/.

50 "Yemen Bomb Attack 'Kills at least 26 people' in Mukalla," BBC News (25 February 2012); доступно на: www.bbc.co.uk/news/world-17164558.

51 Bill Roggio, “AQAP Overruns Yemeni Army Base, Kills 185 Soldiers,” Long War Journal (4 March 2012); доступно на: http://www.longwarjournal.org/archives/2012/03/aqap_overruns yemeni.php.

52 Смотри, наряду с другими: Yaakov Amidror, "Winning Counterinsurgency Wars: The Israeli Experience," JCPA Strategic Perspectives (June 2008); "The Asymmetric Warfare: In Search of a Symmetry"; "The Military Profession and Asymmetric Warfare"; Kilcullen, The Accidental Guerrilla; Frederick Teo Li-Wei, "Rethinking Western Vulnerabilities to Asymmetric Warfare," Journal of the Singapore Armed Forces 2 (2002); and John A. Nagl, Let's Win the Wars We're In (Washington, D.C.: Center for a New American Security, 2009). 
ведение, настолько далекое от нашего понимания жизни, нашей постоянной борьбы уменьшить причины смертности, нашего стремления к благоденствию, или как сформулировано это в Декларации независимости Соединенных Штатов, нашего «стремления к счастью».

Сам факт того, что этим формам борьбы отдается предпочтение и под них подводится теоретическая база в странах Востока (Ближнего и Дальнего), где вертикальный образ мышления превалирует над горизонтальным (или линейным, научным, рациональным), обычным для Запада, делает для нас затруднительным исследование их источника и их путей развития. ${ }^{53}$ Наиболее подходящим, похоже, является подход, при котором за основу берутся конкретные факты, следуя аксиоме Вико, что «verum est ipsum factum» (истина есть то, что ты сам вывел). ${ }^{54}$

53 Смотри работу Люсьена Брушона, который в отношении восточного мышления констатирует: «Аналогическое-интуитивное-ретикулярное мышление не отвергает существование горизонтальных причинных цепочек, но так же признает вертикальную связь подобия между системами, которые только внешне не связаны. Аналогия является примером вертикального мышления, которое высвечивает одновременность явлений, происходящих в разных плоскостях». Lucien Bruchon, "Pensiero logico-razionale-lineare e pensiero analogico-intuitivo-reticolare," эссе доступно на: www.spiritualitaolistica.it/ indice_libro_a.php.

54 Giambattista Vico, De Antiquissima Italorum Sapientia, 1710. Смотри так же: Јames С. Morrison, "Vico's Principle of Verum is Factum and the Problem of Historicism," Journal of the History of Ideas 39:4 (October-December 1978): 579-95. 


\section{Литература}

"Terrorism's Evolution: Yesterday, Today, and Forever." Connections: The Quarterly Journal 10, no. 2 (2011): 1-34.

Caforio, Giuseppe. "The Asymmetric Warfare: In Search of a Symmetry." In Armed Forces and Conflict Resolution: Sociological Perspectives. Bingley, U.K.: Emerald Group Publishing, 2008.

Kaldor, Mary. New and Old Wars: Organized Violence in a Globalized Era In London: Polity Pres., 2005.

Macleod, Scott. "Osama bin Laden: The Paladin of Jihad." Time Magazine (1996).

Morrison, James C.. "Vico's Principle of Verum is Factum and the Problem of Historicism." Journal of the History of Ideas 39, no. 4 (1978): 579-95.

Schalk, Peter. "Historization of the Martial Ideology of the Liberation Tigers of Tamil Eelam (LTTE)." South Asia: Journal of South Asian Studies 20 (1997): 1-38.

Ubayasiri, Kasun. "Leader of Tamil Eelam: An Elusive Leader's Annual Speech.", 2006.

Weimann, Gabriel. How Modern Terrorism Uses the Internet., 2004.

Whitlock, Craig. "Keeping Al-Qaeda in His Grip: Al-Zawahiri Presses Ideology, Deepens Rifts Among Islamic Radicals." Washington Post (2006). 